\title{
Selected council to replace over-democratic body
}

Tokyo

THr newly selected Science Council of Japan is to go into action later this month. And selected, rather than elected, is the word, for the governiment has had its way and turned the often-troublesome freelyelected "parliament of scientists" into a select advisory body. In the process, nearly 80 per cent of its members have been replaced.

Since 1949, the Science Council of Japan has been advising the government on science policy and promoting and coordinating scientific research both nationally and internationally. Its activities have been directed by its 210-member general council and performed through standing committees and research liaison committees involving some 1,500 scientists.

Council members used to be elected in a postal ballot, held every three years, in which virtually all of Japan's 240,000 scientists were qualified to vote. The council was thus perhaps unique among nations in providing all scientists with the right to participate directly in choosing representatives to the highest level of government: the chairman of the council had an automatic right to membership of the Prime Minister's Council for Science and Technology. Numerous successes were scored by the council over the years and many of Japan's finest research facilities grew out of its recommendations including the Nobeyama radio telescope, the Photon Factory, the Institute of Molecular Science and the Polar Research Institute.

But the council ultimately fell prey to a peril for all "grass roots" democracies, the apathy of the "moderate majority". The council has always contained a "peace" lobby which irritated the government by its opposition to nuclear power, by action that succesfully prohibited research on nuclear weapons, and by demanding parliamentary action to guarantee "freedom of research" rights of scientists. It was such people that campaigned most vigorously at election time, not a cheap process for although only the sending of prom otional postcards was permitted, many candidates spent as much as a million yen (US $\$ 4,(00)$ ). Over the years they gained a larger voice in the council.

In return, the government tended to pay less attention to council advice and relied more on its own advisory bodies such as the Ministry of Education's own science council. And that meant that many voters, perceiving the council's power to have lessened, became indifferent to its activities and abandoned it to "left-wingers" whose interest was more political than scientific, or that at least is the story the government would have people believe. The affairs of the council were costing a lot of money, which had to be found by the government. Supervising elections alone, with an electorate of nearly a quarter of a million, cost 100 million yen (US $\$ 400,000$ dollars)

After a few years of dispute with the government (see Nature 305, 361; 1983), the council is now completely reformed (or rendered subservient, depending upon the point of view). Representatives are not directly elected but are chosen at meetings of an electoral college (the Council Selection Management Committee) which is elected, together with candidates for council membership, by the major academic societies.
The new system, along with a rule preventing anyone serving more than three terms of three years each, has led to a dramatic shift in council membership (plus a huge reduction in expenses). Of the 210 members, 163 are new. In come many of the most famous names in Japanese science, as well as a large number of very active researchers who had earlier refused to be involved. The average age of council members rises a couple of years to nearly 63 , perhaps because of the influx of emeritus professors, and so does the number from the Tokyo region, up to 64 per cent of the total. Tokyo University professors alone take 17 per cent of the places, with Kyoto next at 8 per cent. Women too have done a little better, if a change from just one representative to a mere three can be called an improvement.

There is no doubt that the new council contains an extremely distinguished group of scientists who will put science before politics. The test will be whether they pay attention to the wider implications of the expansion of science they will no doubt try to promote.

Alun Anderson

\section{French science}

\section{Horizon freed from bonds}

Paris

FRENCH science seems set for another good year and perhaps for three. When the budget of the French ministry of research came up for parliamentary approval at the end of June, the Prime Minister himself, M. Laurent Fabius, opened the debate.

He told the assembly that "when the question is research, the future of our country is at stake", and said that "the whole effort of this government is found on the triangle of research, training and investment". The fact that the opposition walked out is taken at the ministry as a positive sign for 1986, when the opposition seems likely, by all opinion polls, to be returned to power. Abstentions, or a vote against the budget targets, would have been much worse than a walk-out

The divided opposition in France, led by $\mathbf{M}$. Giscard d'Estaing, $\mathbf{M}$. Jacques Chirac and M. Raymond Barre, can hardly bring itself to vote for anything that the present government has done, when the popularity of the President. M. Francois Mitterand, is at a low ebb. But science and technology are widely thought to be among the government's successes. Thus the innovation director of a Paris company, who "cannot stand" the present government, admitted last week that the attitudes of French academics have now "completely changed". Previously, he said, academics liked to prove that they had no time for practical affairs. Now, they compete for industrial clients.

As for money, M. Fabius told the national assembly, "two periods have marked the development of science in
France. One was under President Mendès-France and one under General de Gaulle." There was a great decline after de Gaulle (beginning with President Pompidou) in which French research and development spending fell from 3 per cent of the gross national product to 1.7 per cent. Now it has been pulled back to 2.25 per cent," which marks a very strong growth since 1980". However, Fabius was careful in his choice of date: M. Mitterrand and his government came to power in 1981, but the science budget was already beginning to increase substantially in 1980 under President Giscard d'Estaing's science minister M. Pierre Aigrain. So science spending is not a party issue.

In the meantime, M. Fabius promised to give science "an absolute priority", backed M. Curien's proposal to raise the research budget by 4 per cent a year in real terms to 1988 , and set his country's sights on reaching 3 per cent of gross national product by $1990-91$. "No science policy is possible without continuity", Fabius said. M. Curien's "thre year plan" will create 1,400 new scientific posts per year, will increase the number of student grants and "develop mobility".

Other themes raised by $M$. Fabius were the linkage of the research community to industry; a "primordial" commitment to scientific development of Europe as a whole and promotion on merit. In forging links with industry and in returning to an academic meritocracy, the present government may ironically have had its greatest success - and lost most of its ideological socialist support

Robert Walgate 